Short Communication

\title{
Lack of Effect of Human Chorionic Gonadotropin in Mixed Lymphocyte Reaction in Xenotransplantation
}

\author{
Abhijit Jagdale ${ }^{\dagger}$, C. Adam Banks ${ }^{\dagger}$, Hayato Iwase, David K.C. Cooper, Hidetaka Hara *
}

Xenotransplantation Program, Department of Surgery, University of Alabama at Birmingham, Birmingham, AL, USA; E-Mails: abhijitjagdale111285@gmail.com; cabanks@uab.edu; hytiv81@gmail.com; dkcooper@uabmc.edu; harahjp@icloud.com

+ These authors contributed equally to this work.

* Correspondence: Hidetaka Hara; E-Mail: harahip@icloud.com

Academic Editor: Haval Shirwan

OBM Transplantation

2021, volume 5 , issue 2

doi:10.21926/obm.transplant.2102146
Received: December 29, 2020

Accepted: June 27, 2021

Published: June 30, 2021

\begin{abstract}
It has been speculated that the immunomodulation associated with pregnancy, e.g., decreasing pro-inflammatory cytokines, increasing anti-inflammatory cytokines, upregulation of T regulatory cells (Tregs), is in part due to the effect of human chorionic gonadotropin (hCG). In this study, we tested the effect of hCG on proliferation of human peripheral blood mononuclear cells (PBMCs) stimulated by irradiated pig PBMCs. Mixed lymphocyte reaction (MLR) was carried out with human PBMCs as responders and irradiated wild-type pig PBMCs as stimulators, with or without $\mathrm{hCG}$. The spontaneous mean proliferation of $\mathrm{CD} 3^{+} \mathrm{T}$ cells was $7 \%$ and, when stimulated by phytohemagglutinin (PHA) was $43 \%$. When stimulated with irradiated wild-type pig PBMCs, $\mathrm{CD}^{+} \mathrm{T}$ cell proliferation was $18 \%$. When hCG (at concentrations of $100 \mathrm{IU} / \mathrm{ml}, 500 \mathrm{IU} / \mathrm{ml}$, and 1,000 IU/ml) was added to the MLR, the proliferation of $\mathrm{CD}^{+} \mathrm{T}$ lymphocytes was $20 \%, 20 \%$, and $18 \%$, respectively. hCG also had no effect on the proliferation of $C D 4^{+} T$ and $C D 8^{+} T$ cells. hCG does not suppress human lymphocyte proliferation stimulated by wild-type pig PBMCs in MLR (unless this is related to an increased number of Tregs, which was not tested in this study).
\end{abstract}

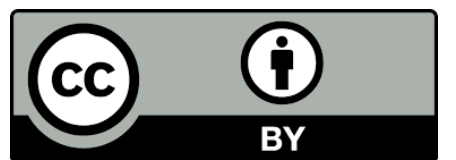

(C) 2021 by the author. This is an open access article distributed under the conditions of the Creative Commons by Attribution License, which permits unrestricted use, distribution, and reproduction in any medium or format, provided the original work is correctly cited. 


\section{Keywords}

Chorionic gonadotropin; human; mixed lymphocyte reaction; pig; T cells; Xenotransplantation

\section{Introduction}

Pregnancy is the single example of foreign tissue avoiding rejection by the host's immune system, without requiring immunosuppressive therapy (Table 1) [1-7]. Human chorionic gonadotropin (hCG) is a heterodimeric glycoprotein primarily produced by syncytiotrophoblasts, often known as the 'pregnancy hormone [8]. The primary functions of hCG in pregnancy are to stimulate progesterone secretion to maintain uterine decidua, and modulate the maternal immune system [8]. In a mouse skin transplantation model, multiparous mice induced tolerance to syngeneic male skin grafts [9], whereas following a single pregnancy there was no significant protective effect on paternal skin allografts [10].

Table 1 Mechanisms active in fetal tolerance during pregnancy and associated observations.

\begin{tabular}{|c|c|}
\hline Reference & Suggested mechanism \\
\hline \multirow[t]{3}{*}[1,2,4]{} & Anatomical barriers (uterus and placenta). \\
\hline & Immature antigen expression by the fetus. \\
\hline & Selective immunosuppressive state of the maternal immune system. \\
\hline$[3,5]$ & Immunomodulation by expression of the HLA-G at feto-maternal surface. \\
\hline [5] & $\begin{array}{l}\text { HLA-G Influences } T \text { cells and Natural Killer cells towards tolerant } \\
\text { phenotypes. }\end{array}$ \\
\hline$[4,6]$ & $\begin{array}{l}\text { Hormones of pregnancy play a role in 'reprogramming' immune cells to a } \\
\text { more immunotolerant phenotype. }\end{array}$ \\
\hline [7] & $\begin{array}{l}\text { Modulation of innate and adaptive immunity by hCG (increased Tregs, } \\
\text { Bregs, and anti-inflammatory cytokines). }\end{array}$ \\
\hline
\end{tabular}

The postulate of hCG as an immunomodulatory molecule capable of influencing conversion to a tolerogenic immunological environment has been explored in many studies (Table 2). It is associated with a decrease in cells producing pro-inflammatory cytokines and an increase in those producing anti-inflammatory cytokines. Transfection of various cell types with hCG plasmid DNA attracts T regulatory cells (Tregs), and in pregnancy there is a greater number of Tregs attracted to the placenta [11-13]. These results suggest that hCG might be used as an immunosuppressive agent in transplantation [14] because of its effect on the regulation of immune reactivity. There are several studies that demonstrate a beneficial effect of hCG on skin allograft survival in mice, although the prolongation of allograft survival was minimal (less than a week) [15-17]. These effects of hCG make the hormone an appealing subject for study in xenotransplantation. 
Table 2 Evidence of effects of hCG during pregnancy.

\begin{tabular}{ll}
\hline Reference & Suggested mechanism \\
\hline$[8,18]$ & $\begin{array}{l}\text { Crucial role of hCG in zygotic implantation, } \\
\text { Improvement of implantation rates with pretreatment of intrauterine hCG } \\
\text { during in vitro fertilization. }\end{array}$ \\
& $\begin{array}{l}\text { In vivo, exogenous hCG influences conversion to a tolerogenic immune } \\
\text { environment by increasing Tregs and anti-inflammatory cytokines. }\end{array}$ \\
& $\begin{array}{l}\text { Recruitment of Tregs to fetomaternal interface. } \\
{[19,20]}\end{array}$ \\
& Lower levels of hCG are associated with spontaneous abortion. \\
{$[21]$} & Promotes a regulatory phenotype of B cells (Bregs). \\
{$[17,22-24]$} & hCG promotes reduction of inflammation by blunting the effects of TNF- $\alpha$ \\
& pathway (in vitro), increasing anti-inflammatory cytokines, e.g., IL-10, IL- \\
& 27, and decreasing pro-inflammatory cytokines, e.g., IL-17 \\
& $\begin{array}{l}\text { Promotion of dendritic cell profile associated with secretion of increased } \\
\text { indoleamine-2,3-dioxygenase and expression of adhesion/costimulatory } \\
\text { molecules. }\end{array}$ \\
\hline
\end{tabular}

The purpose of the present study was to determine whether hCG would suppress the human T cell proliferative response to wild-type (WT) pig peripheral blood mononuclear cells (PBMCs) in vitro.

\section{Materials and Methods}

\subsection{Sources of Human PBMCs}

Institutional Review Board (IRB) approval was obtained for withdrawal of blood from healthy, reproductive age female volunteers who are not on hormonal contraceptive pills $(n=3)$. The samples were obtained in accordance with the Declaration of Helsinki, with the informed consent of the subjects. PBMCs were isolated, as previously described [27].

\subsection{Human Chorionic Gonadotropin (hCG)}

Recombinant hCG (Ovidrel, Merck KGaA, Darmstadt, Germany) ( $250 \mu \mathrm{g}$ in $0.5 \mathrm{ml}$ ) has been documented to be equivalent to $5000 \mathrm{IU}$ urinary gonadotropin [28]. The concentration of hCG selected was $100 \mathrm{IU} / \mathrm{ml}$, as it is the average concentration of hCG in maternal blood during second and third trimesters [29]. We also used high concentrations, i.e. $500 \mathrm{IU} / \mathrm{ml}$ and $1000 \mathrm{IU} / \mathrm{ml}$.

\subsection{CFSE Mixed Lymphocyte Reaction (MLR)}

Freshly harvested human PBMCs were labeled with CFSE, and co-cultured for 6 days with irradiated WT PBMCs with or without hCG, as previously described [30]. Following staining of the cells with the Live/Dead fixable stain kit, flow cytometry was performed using antibodies to CD3 (Pacific Blue, clone SP34-2, BD Pharmingen, San Jose, CA), CD4 (PE-Cy7, clone SK3; BD Pharmingen), and CD8 (PE, clone RPA-T8; BD Pharmingen). Proliferation of subpopulations of human PBMCs was quantified by CFSE dilution (\% CFSE cells). Spontaneous (responders alone) and phytohemagglutinin 
(PHA, Roche, Basel, Switzerland) (final concentration $5 \mu \mathrm{g} / \mathrm{ml}$ )-treated cells were used as negative and positive controls, respectively [30].

\subsection{Statistical Analyses}

Data are presented as mean and standard deviation (SD) for all variables. The statistical significance of differences was determined by non-parametric Kruskal-Wallis tests followed by Dunn's multiple comparisons test, as appropriate, using GraphPad Prism version 7 (GraphPad Software, San Diego, CA). A p value of $<0.05$ was considered to be statistically significant.

\section{Results}

Summary data (Table 3 ) are reported as the means of $\%$ CFSE cells \pm SD ( $n=3$ for each group). There was no significant difference in proliferation of the $C D 3^{+} T, C D 4^{+} T$, or $C D 8^{+} T$ cells when stimulated with irradiated wild-type pig PBMCs with or without hCG (Figure 1).

Table 3 Percentage proliferation of $\mathrm{CD}^{+}, \mathrm{CD}^{+}, \mathrm{CD}^{+} \mathrm{T}$ lymphocytes stimulated by irradiated wild-type pig PBMCs with or without hCG (at 3 different concentrations).

\begin{tabular}{lllllll}
\hline Cells & Spontaneous & $\begin{array}{l}\text { pPBMC+ } \\
\text { hPBMC }\end{array}$ & $\begin{array}{l}\text { pPBMC+ } \\
\text { hPBMC+ hCG } \\
100 \text { IU }\end{array}$ & $\begin{array}{l}\text { pPBMC+ } \\
\text { hPBMC+ } \\
\text { hCG 500 IU }\end{array}$ & $\begin{array}{l}\text { pPBMC+ } \\
\text { hPBMC+ } \\
\text { hCG 1000 IU }\end{array}$ & PHA \\
\hline $\mathrm{CD}^{+} \mathrm{T}$ & $6.929 \pm 1.018$ & $18.25 \pm 4.621$ & $19.50 \pm 6.525$ & $20.40 \pm 4.775$ & $18.00 \pm 3.928$ & $43.29 \pm 16.23$ \\
$\mathrm{CD}^{+} \mathrm{T}$ & $4.929 \pm 1.018$ & $13.63 \pm 2.504$ & $15.00 \pm 2.976$ & $15.40 \pm 1.949$ & $13.88 \pm 2.900$ & $28.57 \pm 17.35$ \\
$\mathrm{CD}^{+} \mathrm{T}$ & $8.786 \pm 0.6986$ & $19.38 \pm 4.779$ & $17.88 \pm 3.271$ & $21.20 \pm 3.962$ & $18.88 \pm 4.190$ & $36.71 \pm 15.85$ \\
\hline
\end{tabular}

hCG = human chorionic gonadotropin; hPBMC = human peripheral blood mononuclear cells; $\mathrm{PHA}=$ phytohemagglutinin; $\mathrm{PPBMC}=\mathrm{WT}$ pig peripheral blood mononuclear cells .

A

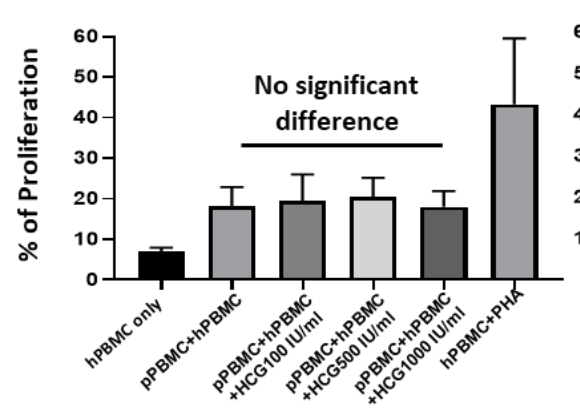

B

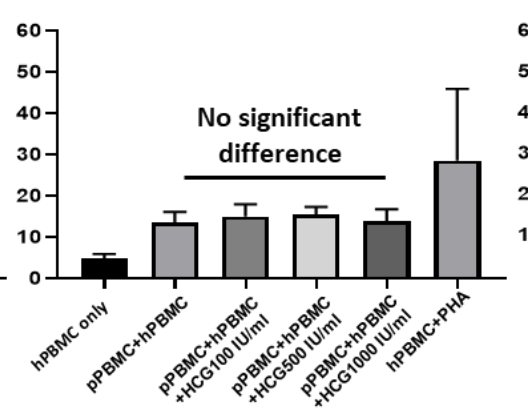

C

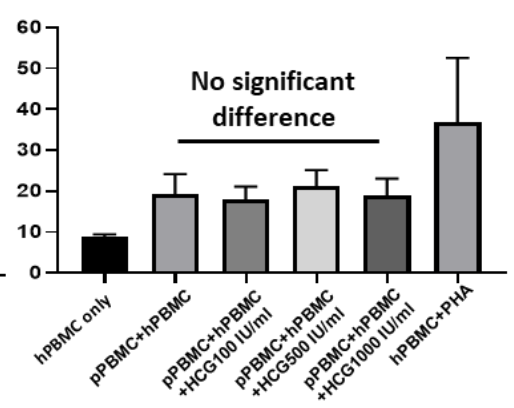

Figure 1 Percentage proliferation of $(\mathrm{A}) \mathrm{CD}^{+},(B) \mathrm{CD}^{+}$, and $(\mathrm{C}) \mathrm{CD} 8^{+} \mathrm{T}$ lymphocytes. From left to right, spontaneous (negative control), when stimulated with irradiated wild-type pig PBMC without (experimental control) or with hCG at three different concentrations or by PHA (positive control). 


\section{Discussion}

The desirable properties of hCG, e.g., upregulation of Tregs and chemoattraction, could be useful in xenotransplantation (Table 2). A number of studies have shown a suppressive effect of crude hCG on lymphocyte proliferation [31-34], but the suppressive effect was not reproducible with purified hCG [35]. One study demonstrated that, when cultured with hCG, there was conversion of

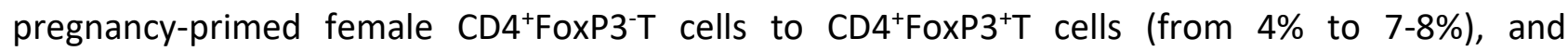
subsequent suppression of autologous and allogeneic lymphocyte proliferation when cultured in the presence of anti-CD3 ${ }^{+}$, anti-CD28 ${ }^{+}$and IL-2 [36].

In the present study, we were unable to detect any suppressive effect of hCG (even at the highest concentration of $1,000 \mathrm{IU} / \mathrm{ml}$ ) on xenogeneic MLR. The absence of suppression of lymphocyte proliferation could be associated with an absence (or minimal number) of Tregs expansion during culture with pig PBMCs [30], even in the presence of hCG. We did not investigate Treg phenotype $\left(\mathrm{CD}^{+} \mathrm{FoxP}^{+}\right)$. To increase the frequency of Tregs, PBMCs would possibly need to be incubated with hCG before setting up the MLR. However, we would have anticipated that, during the 6 days of the MLR, some suppressive effect of hCG on T cell proliferation would have been observed.

Limitations of our study include that we tested hCG from only one source, though we have no reason to believe that hCG from other sources may have been more effective. Neither did we test the effect of hCG on human antibody binding to pig PBMCs, nor on human serum cytotoxicity of pig PBMCs, but there is no evidence to suggest that hCG would have any impact in this respect.

Although this small study had a negative result, we believe that, in the light of previous studies of hCG in allotransplantation, it is important to report our data, which we believe are the first reported in a pig-to-human xenotransplantation model.

\section{Conclusions}

Our limited study suggests that hCG does not suppress human lymphocyte proliferation stimulated by pig PBMCs (unless this results from an increase in the number of Tregs, which we did not investigate).

\section{Abbreviations}

hCG = human chorionic gonadotropin

$\mathrm{MLR}=$ mixed lymphocyte reaction

PBMCs = peripheral blood mononuclear cells

Tregs $=$ T regulatory cells

\section{Author Contributions}

AJ participated in the performance of the research, data collection, statistical analysis and in the writing of the paper. $\mathrm{CAB}$ and $\mathrm{HI}$ participated in the performance of the research and in the review of the paper. DKCC participated in research design and in writing the paper. $\mathrm{HH}$ participated in research design, the performance of the research, and writing the paper. $\mathrm{HH}$ is the guarantor of this work and, as such, had full access to all the data in the study and takes responsibility for the integrity of the data and the accuracy of the data analysis. 


\section{Funding}

Work by our group on xenotransplantation at UAB is supported in part by NIH grant \#U19 Al090959/08 and in part by a grant to UAB from United Therapeutics, Silver Spring, MD.

\section{Competing Interests}

The authors have declared that no competing interests exist.

\section{References}

1. Medawar PB. Some immunological and endocrinological problems raised by the evolution of viviparity in vertebrates. Symp Soc Exp Biol. 1953; 7: 320-337.

2. Billingham RE. Transplantation immunity and the maternal-fetal relation. N Engl J Med. 1964; 270: 720-725.

3. Ober C. HLA and pregnancy: The paradox of the fetal allograft. Am J Hum Genet. 1998; 62: 1-5.

4. Billington WD. The immunological problem of pregnancy: 50 years with the hope of progress. A tribute to Peter Medawar. J Reprod Immunol. 2003; 60: 1-11.

5. Hunt JS, Petroff MG, McIntire RH, Ober C. HLA-G and immune tolerance in pregnancy. FASEB J. 2005; 19: 681-693.

6. Schumacher A, Costa SD, Zenclussen AC. Endocrine factors modulating immune responses in pregnancy. Front Immunol. 2014; 5: 196.

7. Schumacher A. Human chorionic gonadotropin as a pivotal endocrine immune regulator initiating and preserving fetal tolerance. Int J Mol Sci. 2017; 18: 2166.

8. Cunningham FG, Leveno KJ, Bloom SL, Dashe JS, Hoffman BL, Casey BM, et al. Chapter 5: Implantation and placental development. In: Williams Obstetrics 24/E. New York: McGraw-Hill Medical; 2014. pp.80-116.

9. Smith RN, Powell AE. The adoptive transfer of pregnancy-induced unresponsiveness to male skin grafts with thymus-dependent cells. J Exp Med. 1977; 146: 899-904.

10. Shou Z, Xu Y, Xiao H, Zhou Q, Cai J, Yang Y, et al. The effect of pregnancy on paternal skin allograft survival. Sci China C Life Sci. 2009; 52: 1011-1015.

11. Fuchs $\mathrm{T}$, Hammarström $\mathrm{L}$, Smith $\mathrm{Cl}$, Brundin J. In vitro induction of human suppressor T cells by a chorionic gonadotropin preparation. J Reprod Immunol. 1981; 3: 75-84.

12. Tilburgs T, Roelen DL, van der Mast BJ, de Groot-Swings GM, Kleijburg C, Scherjon SA, et al. Evidence for a selective migration of fetus-specific $C D 4^{+} C D 25^{\text {bright }}$ regulatory $T$ cells from the peripheral blood to the decidua in human pregnancy. J Immunol. 2008; 180: 5737-5745.

13. Schumacher A, Brachwitz N, Sohr S, Engeland K, Langwisch S, Dolaptchieva M, et al. Human chorionic gonadotropin attracts regulatory $T$ cells into the fetal-maternal interface during early human pregnancy. J Immunol. 2009; 182: 5488-5497.

14. Theofanakis C, Drakakis P, Besharat A, Loutradis D. Human chorionic gonadotropin: The pregnancy hormone and more. Int J Mol Sci. 2017; 18: 1059.

15. Pearse $\mathrm{WH}$, Kaiman $\mathrm{H}$. Human chorionic gonadotropin and skin homograft survival. Am J Obstet Gynecol. 1967; 98: 572-574.

16. Pearse $W H$, Curtis GL. Skin allograft survival and lowered maternal immunologic reactivity. Am J Obstet Gynecol. 1969; 104: 419-420. 
17. Koldehoff $M$, Katzorke $T$, Wisbrun NC, Propping $D$, Wohlers $S$, Bielfeld $P$, et al. Modulating impact of human chorionic gonadotropin hormone on the maturation and function of hematopoietic cells. J Leukoc Biol. 2011; 90: 1017-1026.

18. Santibañez Á, García J, Pashkova O, Colín O, Castellanos G, Sánchez AP, et al. Effect of intrauterine injection of human chorionic gonadotropin before embryo transfer on clinical pregnancy rates from in vitro fertilisation cycles: A prospective study. Reprod Biol Endocrinol. 2014; 12: 9.

19. Somerset DA, Zheng $Y$, Kilby MD, Sansom DM, Drayson MT. Normal human pregnancy is associated with an elevation in the immune suppressive $\mathrm{CD} 25^{+} \mathrm{CD} 4^{+}$regulatory $\mathrm{T}$-cell subset. Immunology. 2004; 112: 38-43.

20. Sha J, Liu F, Zhai J, Liu X, Zhang Q, Zhang B. Alteration of Th17 and Foxp3 ${ }^{+}$regulatory T cells in patients with unexplained recurrent spontaneous abortion before and after the therapy of hCG combined with immunoglobulin. Exp Ther Med. 2017; 14: 1114-1118.

21. Fettke F, Schumacher A, Canellada A, Toledo N, Bekeredjian-Ding I, Bondt A, et al. Maternal and fetal mechanisms of $B$ cell regulation during pregnancy: human chorionic gonadotropin stimulates B cells to produce IL-10 while alpha-fetoprotein drives them into apoptosis. Front Immunol. 2016; 7: 495.

22. Manna SK, Mukhopadhyay A, Aggarwal BB. Human chorionic gonadotropin suppresses activation of nuclear transcription factor- $\mathrm{kB}$ and activator protein-1 induced by tumor necrosis factor. J Biol Chem. 2000; 275: 13307-13314.

23. Rolle L, Memarzadeh Tehran M, Morell-García A, Raeva Y, Schumacher A, et al. Cutting edge: IL-10-producing regulatory $B$ cells in early human pregnancy. Am J Reprod Immunol. 2013; 70: 448-453.

24. Muzzio D, Zygmunt $M$, Jensen $F$. The role of pregnancy-associated hormones in the development and function of regulatory B cells. Front Endocrinol. 2014; 5: 39.

25. Yoshimura T, Inaba M, Sugiura K, Nakajima T, Ito T, Nakamura K, et al. Analyses of dendritic cell subsets in pregnancy. Am J Reprod Immunol. 2003; 50: 137-145.

26. Wan H, Versnel MA, Leijten LM, van Helden-Meeuwsen CG, Fekkes D, Leenen PJ, et al. Chorionic gonadotropin induces dendritic cells to express a tolerogenic phenotype. J Leukoc Biol. 2008; 83: 894-901.

27. Hara H, Ezzelarab M, Rood PP, Lin YJ, Busch J, Ibrahim Z, et al. Allosensitized humans are at no greater risk of humoral rejection of GT-KO pig organs than other humans. Xenotransplantation. 2006; 13: 357-365.

28. Allahbadia G. Recombinant or urinary human chorionic gonadotropin in ovulation induction? J Obstet Gynaecol India. 2011; 61: 621-623.

29. Korevaar TI, Steegers EA, de Rijke YB, Schalekamp-Timmermans S, Visser WE, Hofman A, et al. Reference ranges and determinants of total hCG levels during pregnancy: The generation $R$ study. Eur J Epidemiol. 2015; 30: 1057-1066.

30. Lin YJ, Hara H, Tai HC, Long C, Tokita D, Yeh P, et al. Suppressive efficacy and proliferative capacity of human regulatory $T$ cells in allogeneic and xenogeneic responses. Transplantation. 2008; 86: 1452-1462.

31. Kaye MD, Jones WR. Effect of human chorionic gonadotropin on in vitro lymphocyte transformation. Am J Obstet Gynecol. 1971; 109: 1029-1031.

32. Purtilo DT, Hallgren HM, Yunis EJ. Depressed maternal lymphocyte response to 
phytohaemagglutinin in human pregnancy. Lancet. 1972; 1: 769-771.

33. Adcock EW, Teasdale F, August CS, Cox S, Meschia G, Battaglia FC, et al. Human chorionic gonadotropin: its possible role in maternal lymphocyte suppression. Science. 1973; 181: 845847.

34. Contractor SF, Davies H. Effect of human chorionic somatomammotrophin and human chorionic gonadotrophin on phytohaemagglutinin-induced lymphocyte transformation. Nat New Biol. 1973; 243: 284-286.

35. Han T. Inhibitory effect of human chorionic gonadotrophin on lymphocyte blastogenic response to mitogen, antigen and allogeneic cells. Clin Exp Immunol. 1974; 18: 529-535.

36. Poloski E, Oettel A, Ehrentraut S, Luley L, Costa SD, Zenclussen AC, et al. JEG-3 trophoblast cells producing human chorionic gonadotropin promote conversion of human $\mathrm{CD}^{+}{ }^{+} \mathrm{FOXP3}^{-} \mathrm{T}$ cells into $\mathrm{CD}^{+}{ }^{+} \mathrm{FOXP3}^{+}$regulatory T cells and foster T cell suppressive activity. Biol Reprod. 2016; 94: 106.

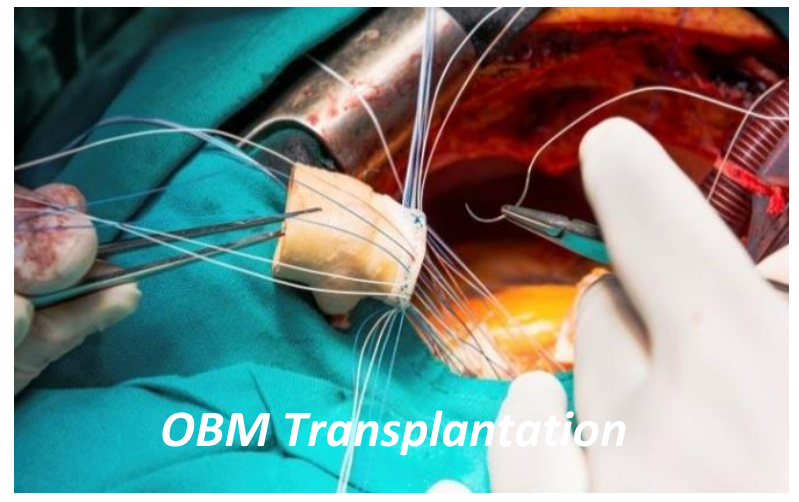

Enjoy OBM Transplantation by:

1. Submitting a manuscript

2. Joining in volunteer reviewer bank

3. Joining Editorial Board

4. Guest editing a special issue

For more details, please visit:

http://www.lidsen.com/journals/transplantation 